\title{
Faste stillinger for leger i spesialisering - nødvendig og fremtidsrettet
}

\author{
Langsiktighet i arbeidsforhold er viktig for både arbeidstaker og arbeidsgiver. Den eneste fremtidsrettede \\ løsningen er at leger i spesialisering gis fast ansettelse. Det vil helsetjenesten tjene på.
}

«Mange av oss yngre var nokså skuffet over at Lægeforeningen ikke gikk inn for bedring av sykehuslægenes stillinger; økonomiske forhold, arbeidsmengden, uregelmessigheter ved ansettelser, lægenes vanskeliges stilling i sykdomstilfelle.» Slik oppsummerte den første lederen i Yngre legers forening (Ylf) Einar Onsum noe av motivasjonen for å opprette en egen forening for underordnede leger da Ylf hadde 50-årsjubileum i 1961 (1). Siden den tid har situasjonen for yngre leger blitt bedre på mange områder. Samarbeidet med Legeforeningen er godt og gjensidig utviklende, lønnsforholdene er akseptable og arbeidstiden er regulert. Men utfordringer finnes fremdeles. Mange finner arbeidsmiljøet vanskelig og at det ikke er god balanse kan foreligge avtaler i arbeidsforholdet om målrettet mobilitet. Selvfølgelig må vi ha en modell som ivaretar de mange hensyn i spesialistløpet. Dette er Legeforeningen og arbeidsgiversiden enige om.

Samtidig som ansettelsene av leger i spesialisering er blitt endret i retning av kortere varighet, har det utviklet seg en praksis med ulovlig bruk av vikariater. En vikar skal dekke opp for fraværet av stillingseier. Tidsbegrensningen skal tilsvare perioden stillingseier er borte. Dette praktiseres sjelden i helseforetakene i dag. Vikariater uten klar spesifikasjon for hvem det vikarieres for og av til dels svært kort varighet (to uker i ekstreme tilfeller) er nå vanlig. Uhjemlet tidsbegrensning sprer seg også til overlegestillinger. Dette er særlig

\section{«De regionale helseforetakene må ta ansvaret for å opprette det antall utdanningsstillinger som trengs for å kunne tilby likeverdige og forsvarlige helsetjenester»}

mellom oppgaver og ressurser. Uregelmessigheter ved ansettelser er vanlig, og dette har tiltatt de siste årene.

Norsk arbeidsliv er basert på faste ansettelser - først og fremst begrunnet i behovet for stabilitet, trygghet og langsiktighet, ikke bare ut fra hensynet til arbeidstakere. Dette gjelder også i sykehus, hvor både Legeforeningen og de politiske myndighetene er opptatt av faste stillinger og den betydning dette har for pasientsikkerheten. Langsiktighet i kompetansebygging og rekruttering gir mulighet for å utvikle stabile fagmiljøer og tydeliggjør betydningen av god supervisjon og veiledning. Leger i spesialisering forteller om frykt for å ta opp vanskelige saker som angår pasientsikkerhet og arbeidsvilkår og om frykten for å virke «vanskelig». Utrygghet i jobben gir også utrygghet i privatlivet. Det kortsiktige arbeidsforholdet til leger i spesialisering må erstattes med langsiktighet og ansvar.

Faste stillinger betyr ikke mangel på mobilitet. Det betyr heller ikke at det ikke aktuelt i overgangen fra lege i spesialisering til overlege, men ses ved visse avdelinger også langt ut i overlegenes arbeidsforhold.

Det er vanlig at leger i helseforetakene tilbringer de første 10-15 årene av sin yrkeskarriere i tidsbegrensede stillinger, noe som ikke er i tråd med gjeldende regler eller arbeidslivets verdigrunnlag. Nå dikteres premissene for ansettelsesvarighet av arbeidsgiver alene. Ensidig å sette viktige prinsipper til side strider mot de verdier det norske arbeidslivet er tuftet på. Langsiktighet er viktig for både arbeidstaker og arbeidsgiver. Den eneste fremtidsrettede løsningen er at leger i spesialisering gis fast ansettelse.

Helseministeren slo høsten 2010 fast at leger i spesialisering som hovedregel skal ansettes fast, samtidig som man skal sikre god og effektiv spesialisering (2). Dette todelte målet deles av Legeforeningens landsstyre (3), Ylfs landsråd (4) og arbeidsgiverforeningen Spekter (5). Dette skal sikres gjennom riktig dimensjonering av antall faste stillinger og rotasjonsplasser. Samarbeidsavtaler om spesialisering mellom små og store sykehus vil kunne bidra til færre propper i systemet enn det er i dag. Legeforeningen legger også til grunn en trinnvis innføring av faste stillinger. Man må starte med dagens gruppe II-sykehus og utvide til større sykehus og universitetssykehus i takt med dimensjoneringen av faste stillinger og rotasjonsplasser.

Legeforeningen har også foreslått at det lovfestede legefordelingssystemet avvikles (6). Dette ble innført i en tid med legeunderskudd og skulle hindre at leger kun ble rekruttert til sentrale institusjoner. I dag er situasjonen annerledes, og det er vanskelig å se for seg ukontrollert ansettelse av leger. Arbeidsgiversiden må i større grad tenke langsiktig og kartlegge det fremtidige behov for ulike spesialister. Riktig dimensjonering av spesialistutdanningen må være sentralt. De regionale helseforetakene må ta ansvaret for å opprette det antall utdanningsstillinger som trengs for å kunne tilby likeverdige og forsvarlige helsetjenester. Det blir altså opp til arbeidsgiversiden å dimensjonere riktig slik at nødvendig spesialiseringskapasitet opprettholdes på lang sikt.

Vi må forlate negative incitamenter for rekruttering, slik som at man etter endt spesialisering tvinges til å ta jobb på mindre attraktive steder. Isteden må arbeidsgiversiden komme på tilbudssiden når de skal skaffe seg attraktiv, nødvendig og høykompetent arbeidskraft. Dette handler om holdninger og profesjonell tilnærming til rekruttering og kompetansebygging, noe man må forvente at helseforetakene har.

Det haster med å innføre faste stillinger for leger i spesialisering. Både regjeringen og et samlet Storting har stilt seg bak omleggingen. Vi forventer at arbeidsgiversiden starter opp implementeringen snarest. I over 100 år har man eksperimentert med ulike midlertidige ordninger som ikke har ivaretatt de behov et ansettelsesforhold skal dekke. Omleggingen forutsetter at man forlater den kortsiktige og ansvarsfraskrivende holdningen overfor leger i spesialisering og innser at man må vurdere disse langsiktig og forpliktende. Det vil helsetjenesten tjene på.

\section{Johan Torgersen}

johan.torgersen@legeforeningen.no

Yngre legers forening 
Johan Torgersen (f. 1974) er spesialist i anestesiologi og ph.d. fra Universitetet i Bergen. Han har vært tillitsvalgt i Yngre legers forening (Ylf) siden 2007 og har nå permisjon fra stillingen som lege i spesialisering ved Haukeland universitetssykehus for å være leder i foreningen. Torgersen er også medlem av Legeforeningens sentralstyre.

Ingen oppgitte interessekonflikter.

\section{Litteratur}

1. Onsum E. Stiftelsen av «Yngre lægers forening». Tidsskr Nor Lægeforen 1961; 81: 1327-9.

2. Flere yngre leger får faste stillinger. Helse og omsorgsdepartementet, pressemelding nr. 56/2010. www.regjeringen.no/nb/dep/hod/ pressesenter/pressemeldinger/2010/Flere-yngreleger-far-faste-stillinger.html?id=615814

$$
\text { (2.4.2012). }
$$

3. Resolusjon i Landsstyret for Den norske Legeforening om faste stillinger. Tidsskr Nor Legeforen 2009; 129: 1504-5

4. Ylfs policydokument om spesialistutdanning https://legeforeningen.no/yf/Yngre-legersforening/viktige-dokumenter/spes/ (2.4.2012).

5. Tilrettelegging av fast ansettelse av leger i spesialisering. Rapport fra en arbeidsgruppe 12.12.2011 nedsatt av de fire regionale helseforetakene. Oslo: Spekter, 2012.

6. Lov 1999-07-02 nr. 61. Lov om spesialisthelsetjeneste m.m.

Mottatt 13.4. 2012, første revisjon innsendt 24.4. 2012, godkjent 24.4. 2012. Medisinsk redaktør Are Brean. 